2013-01-0523

\title{
Diesel Emissions with DPF \& SCR and Toxic Potentials with BioDiesel (RME) Blend Fuels
}

J. Czerwinski,

AFHB

P. Dimopoulos Eggenschwiler, N. Heeb, A. Liati

EMPA

M.C. Astorga

JRC

A. Mayer

TTM

A. Heitzer,

EV

G. D'Urbano,

BAFU

S. Hermle, S. Renz

Renz Consulting

\section{ABSTRACT}

The use of alternative fuels and among them the biofuels of $1^{\text {st }}$ generation - fatty acid methyl esters FAME's ${ }^{*}$ and pure plants oils - for propulsion of IC engines is an important objective in several countries in order to save the fossil fuels and to limit the $\mathrm{CO}_{2}$-production.

The properties of bio-fuels and bio-blend-fuels can vary and this has an impact on the operation and emissions of Diesel engines and on the modern exhaust aftertreatment systems.

The present paper represents the most important results obtained with RME at AFHB, EMPA and EC-JRC. Most of the activities were performed in the network project BioExDi (Biofuels, Exhaust Systems Diesel) in collaboration between industry and research institutes.

Following most important statements can be given about the treated subjects:

- emissions (engine-out) are influenced by RME in the sense less $\mathrm{CO}, \mathrm{HC} \& \mathrm{PM}$, more $\mathrm{NO}_{\mathrm{x}}$ and more SOF,

- there are positive influences of RME on the functionality of DOC and DPF due to higher reactivity of RME, no influence on SCR,

- the long term functionality of exhaust aftertreatment systems with RME can be influenced by the potential higher availability of elements, like $\mathrm{Ca}, \mathrm{Mg}, \mathrm{Zn}, \mathrm{P}, \mathrm{S}, \mathrm{K}$,

- regarding particle mass PM: without DPF there are slight tendencies of lowering TEQ at low load with RME and increasing TEQ at high load of the engine; with DPF there is a strong reduction of all toxic substances and there are no effects of RME on PAH \& TEQ.

Some practical recommendations for the users of biofuels of the $1^{\text {st }}$ generation are given at the end of the paper. Generally there is a necessity of higher costs and efforts for more frequent service and maintenance and for the quality controls of fuel and fuel supply chain.

*) Abbreviations see at the end of this paper 


\section{INTRODUCTION AND PRELIMINARY INFORMATION}

\section{Application of RME in IC Engines}

Rapeseed Oil Methyl Ester (RME), called also bio-diesel is one of many Fatty Acid Methyl Esters (FAME), which can be produced from different primary vegetable oils, like soya oil, palm oil, coconut oil, sunflower oil and others.

RME (FAME) can principally be used in all Diesel engines without changes of injection system. Due to the lower heat value it causes lower full load characteristics of the engine.

RME can be aggressive against different materials, especially sealings, paints, rubber and other synthetics. It provokes a quicker oil dilution and deterioration of oil quality - more frequent oil exchange intervals as well as special oils are recommended.

RME, as all bio-fuels, is bio-degradable and $\mathrm{CO}_{2}$-neutral.

Thanks to the oxygen content (10.7\%) RME can lower the emissions of $\mathrm{CO}, \mathrm{HC}$ including aromatics, aldehydes \& ketones, [1].

RME produces a lower part of insoluble fraction (INSOF) in the particle mass and it often causes higher particle number concentrations in the nuclei mode (the lowest invisible size range $<40 \mathrm{~nm}$ ) due to the spontaneous condensates, $[1,2]$.

The soluble fraction (SOF) with RME has the lowest mutagenous effects, [1].

The comparison of PM-emissions with RME and standard fuel depends on the working collective of the engine, since the operating regime influences the SOF/INSOF proportion and RME provokes more deposited soluble organic fraction (SOF).

In an extensive study of the US EPA, [3], with blending of $20 \%$ soja oil methyl ester (SME), following average changes were found:

$\mathrm{NO}_{\mathrm{x}}+2 \% ; \mathrm{PM}-10,1 \%, \mathrm{HC}-21,1 \% ; \mathrm{CO}-11.0 \%$

In contrary to that a Swiss research program, [4], found no significant improvements of emissions $\mathrm{CO}, \mathrm{HC} \& \mathrm{PM}$ with 15\% RME blends. The statements about PM-composition and about NP-count concentrations could be confirmed:

- EC share of the PM: significantly less than for diesel fuel, decreasing with increasing RME-content.

- OC share of the PM: much more than with diesel fuel and increasing with RME content.
- Smoke emission: noticeably diminished black smoke and opacity, both steady-state and transient conditions, improving with higher RME content.

- Particle size distribution: consistent curtailment of particles larger than $80 \mathrm{~nm}$ but some increase, at all operating states, of particles smaller than $80 \mathrm{~nm}$.

Further important information about biofuels can be found in $[5,6,7,8]$.

\section{DPF regeneration, soot oxidation \& structure}

The impact of blending 20\% SME (soya methyl ester) to Diesel fuel on the regeneration of a catalyzed DPF was investigated in [9] (US) on a Cummins 6 cyl. 5.9 L engine. The used tools were: the traditional engine diagnostics for injection, combustion and limited emissions, as well as analytics of soot composition and structure. It was shown, that biodiesel blending alters the composition of the particulate matter (PM), as well as the nanostructure of the primary soot particles and thereby alters the regeneration behaviour of DPF. The inclusion of biodiesel in the base fuel reduces the temperature required to initiate the regeneration. This is attributed to the changed nanostructure and oxidation reactivity of the primary soot particles, yielding a more amorphous soot structure, which enhances the soot oxidation.

In [10] the same researchers group focused on the mechanisms of oxidation of biofuel soot (B100, SME) and confirmed that due to different structure and oxygen content the B100 soot is more reactive and undergoes a different oxidation process, than the soot derived from Diesel fuel (ULSD \& FT). By means of partial oxidations and a detailed analysis of soot structure it was shown that the crucial mechanism by which biodiesel soot enhances oxidation is a structural transformation of the surface of the soot conglomerates in the early stage of oxidation, whereby the initial surface oxygen groups are more important than the initial structure and pore size distribution.

In [11] the effects of biodiesel blends (B20 \& B100, SME) were investigated on a Cummins engine 5.9L with a catalyzed CRT (continuously regenerating trap). Significant lowering of the balance point temperature $\left(\Delta \mathrm{t} 45^{\circ} \mathrm{C}\right.$ with $\mathrm{B} 20 \Delta \mathrm{t} 112^{\circ} \mathrm{C}$ with $\mathrm{B} 100)$, as well as an increase of regeneration rate was found. If it would be possible to renounce on active regeneration system due to the use of biofuels, this would mean a supplementary energy saving. 
Also the researchers in [12], investigated B50 \& B100 (seed oils methyl ester) on two engines, found differences of morphology (SEM), differences of chemistry and more easy passive regeneration of DPF with biocomponents. It is suggested that potassium contained in the investigated oils might assist in formation of inorganic substances, which would catalytically lower the ignition temperature of the soot.

\section{Objectives}

The objective of the present paper is to summarize the most important results obtained by AFHB and by the collaborating laboratories EMPA- and JRC-analytics during the project activities with RME.

There is information about:

- emissions without \& with DPF with Bxx,

- influences of RME on PM \& PN, EC \& OC,

- soot loading, regeneration and anatomy of DPF,

- secondary emissions and traces with SCR \& RME,

- DOC light-off with Bxx,

- TEQ with Bxx, SCR \& DPF (particle mass from some characteristic test series were investigated at JRC Ispra on PAH, TEF and TEQ).

Additionally several practical remarks and recommendations have been given, which would help the user of biofuels FAME's to attain a satisfactory engine operation with possibly lowest exhaust emissions and energy consumption.

\section{TESTED ENGINES \& FUELS}

\section{Engines}

Liebherr engine for construction machines was used during the projects with RME. Due to the collaboration with the engine manufacturer an access to the engine ECU was given, which enabled the setting of certain parameters and of the full load characteristics.

For testing of SCR-, or (DPF+SCR) - systems an IVECO engine (Euro 3) was used. This engine is attached to a dynamic brake, which makes possible to perform all kinds of dynamic testing.

The engines data are summarized in Table 1.

Figure 1 shows Liebherr engine and Figure 2 the Iveco engine in the laboratory for IC-engines, University of Applied Sciences, Biel-Bienne.
Table 1: Data of the research engines in the RME-research programs

\begin{tabular}{|c|c|c|}
\hline Manufacturer & $\begin{array}{c}\text { Liebherr Machines } \\
\text { Bulle S.A., } \\
\text { Bulle/Fribourg } \\
\end{array}$ & Iveco, Torino Italy \\
\hline Type & D934 S & F1C Euro 3 \\
\hline Displacement & 6.36 Liters & 3.00 Liters \\
\hline RPM & $2000 \mathrm{rpm}$ & $\max .4200 \mathrm{rpm}$ \\
\hline Rated power & $\begin{array}{c}111 \mathrm{~kW} \\
2000 \mathrm{rpm}\end{array}$ & $\begin{array}{c}100 \mathrm{~kW} @ \\
3500 \mathrm{rpm}\end{array}$ \\
\hline Model & 4 cylinder in-line & 4 cylinder in-line \\
\hline $\begin{array}{l}\text { Combustion } \\
\text { process }\end{array}$ & direct injection & direct injection \\
\hline $\begin{array}{l}\text { Injection } \\
\text { system }\end{array}$ & Bosch unit pumps & $\begin{array}{l}\text { Bosch Common } \\
\text { Rail (CR) } 1600 \text { bar }\end{array}$ \\
\hline Supercharging & $\begin{array}{l}\text { Turbocharger with } \\
\text { intercooling }\end{array}$ & $\begin{array}{l}\text { Turbocharger with } \\
\text { intercooling }\end{array}$ \\
\hline $\begin{array}{l}\text { Emission } \\
\text { control }\end{array}$ & $\begin{array}{c}\text { none } \\
\text { (exhaust gas } \\
\text { aftertreatment } \\
\text { according to the } \\
\text { requirements) }\end{array}$ & none \\
\hline $\begin{array}{l}\text { Development } \\
\text { period }\end{array}$ & 2005 & until 2000 \\
\hline
\end{tabular}

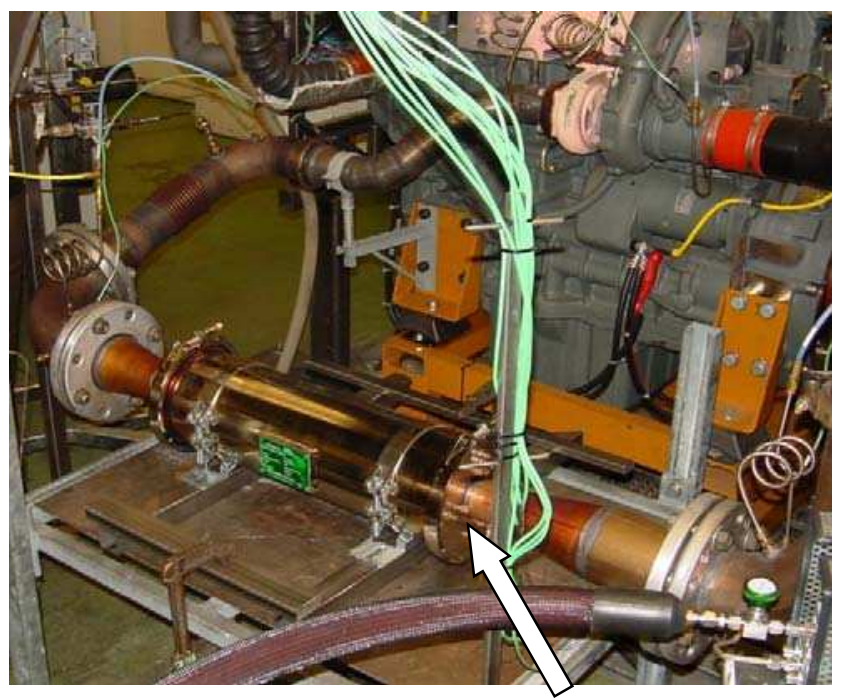

DPF installed in the exhaust line

Figure 1 - Investigation of DPF on the LIEBHERR engine D934 


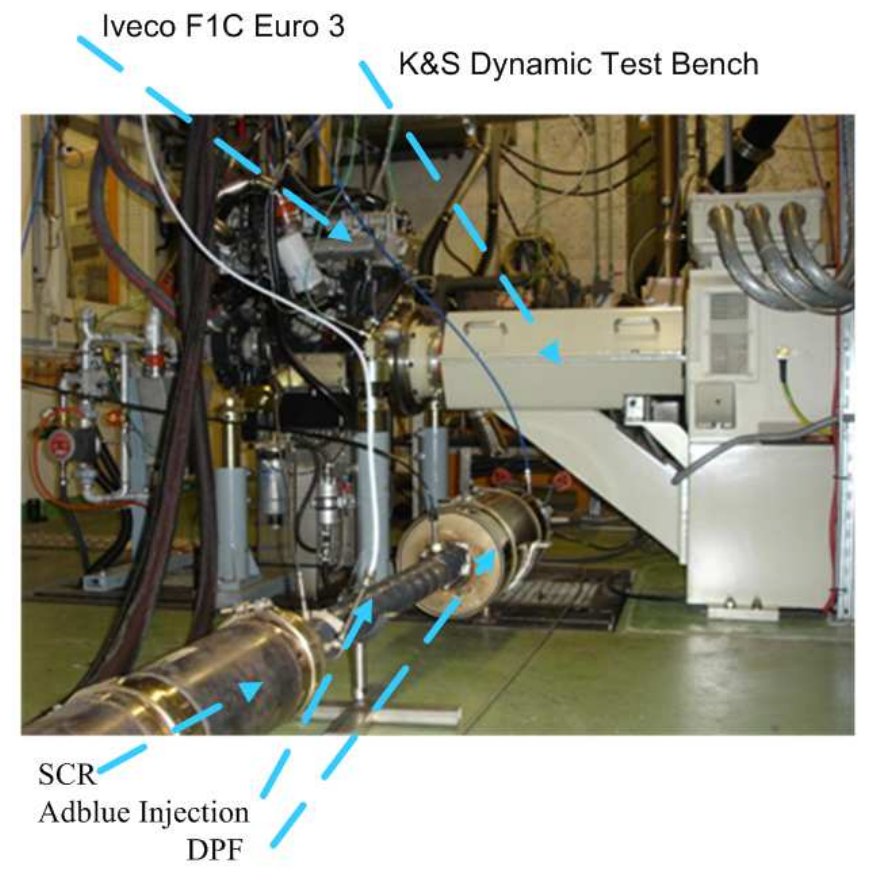

Figure 2 - (DPF + SCR) system on the Iveco engine F1C

\section{Fuels}

Following base fuels were used for the research (Table 2):

- Shell Formula Diesel fuel Swiss market summer quality (10 ppm S) according to SN EN 590

- $\quad$ Rapeseed Oil Methyl Ester RME from Flamol, Berne, CH

Table 2 represents the most important data of the fuels according to the standards and the analysis certificates.

It can be remarked, that there are differences of density, heat value, stoichiometric air requirement and boiling range, which have influences on the engine operation and especially on the full load parameters. These changing fuel parameters are taken into account by the evaluation of measurements. The resulting fuel parameters for the blend fuels are represented in Table 3 .

For the reasons of market the testing of fuels with low RME blending ratio (B7 \& B10) is required. This usually makes no difference of results to the pure Diesel fuel. Therefore for the reasons of research higher blending ratios (B20, B30 \& B100) were used in order to may indicate the maximum differences.
Table 2 - Fuel properties as per EU-standards and further analysis of the test fuels

\begin{tabular}{|c|c|c|}
\hline & Diesel & RME \\
\hline Density at $15^{\circ} \mathrm{C}$ & $0.832 *$ & $0.845^{*}$ \\
\hline Viscosity at $40^{\circ} \mathrm{C}$ & $2.0-4.5$ & $4.6^{*}$ \\
\hline Flash point & above $55^{\circ} \mathrm{C}$ & $143^{\circ} \mathrm{C}$ \\
\hline Cloud point & $\max -10^{\circ} \mathrm{C}$ & - \\
\hline Filterability CFPP & $\max -20^{\circ} \mathrm{C}$ & -15 \\
\hline Ash & $\max 0.010$ & Traces \\
\hline Sulfur & $<10$ & $1.3^{*}$ \\
\hline Cetane Number & 51 & 56 \\
\hline Calorific value & 42.7 & 37.2 \\
\hline C fraction & 86.7 & 77.5 \\
\hline $\mathrm{H}$ fraction & 13.3 & 11.8 \\
\hline O fraction & 0 & 10.7 \\
\hline $\mathrm{kg} / \mathrm{kg}$ & 14.52 & 12.49 \\
\hline Boiling range $10-90 \%{ }^{\circ} \mathrm{C}$ & $180-340$ & $315-360$ \\
\hline
\end{tabular}

Table 3 - Principal parameters of the blend fuels

\begin{tabular}{|c|c|c|c|}
\cline { 2 - 4 } \multicolumn{1}{c|}{} & $\begin{array}{c}\rho\left(20^{\circ}\right. \\
\mathrm{C}) \\
{[\mathrm{kg} / \mathrm{d}} \\
\left.\mathrm{m}^{3}\right]\end{array}$ & $\begin{array}{c}\mathrm{Hu} \\
{[\mathrm{MJ} /} \\
\mathrm{kg}]\end{array}$ & $\begin{array}{c}\text { Air min } \\
{\left[\mathrm{kg}_{\mathrm{A}} /\right.} \\
\mathrm{kg}\end{array}$ \\
\hline Diesel & 0.832 & 42.70 & 14.52 \\
\hline RME 7 & 0.835 & 42.30 & 14.38 \\
\hline $\begin{array}{c}\text { RME } \\
20\end{array}$ & 0.842 & 41.55 & 14.10 \\
\hline $\begin{array}{c}\text { RME } \\
30\end{array}$ & 0.846 & 40.98 & 13.89 \\
\hline $\begin{array}{c}\text { RME } \\
100\end{array}$ & 0.880 & 37.20 & 12.49 \\
\hline
\end{tabular}

\section{TEST METHODS AND INSTRUMENTATION}

\section{Engine dynamometers and standard test equipment}

Figure 3 represents the special systems installed on the engine, or in its periphery for analysis of the legislated and nonlegislated emissions on Iveco engine. The positions of measured control parameters $(p, T)$ in different positions of the air- and gas path are marked. 
For research different sampling positions (SP) in the exhaust system were used. For combined exhaust aftertreatment systems (DPF + SCR) a DPF is mounted between SP1 and $\mathrm{SP} 2,[13,14,15]$.

The SCR-system has its own ECU and control sensors $\left(\mathrm{NO}_{\mathrm{x}}\right.$ and temperature).

The test stand of Liebherr engine is equipped with a eddy current dynamometer, with similar measuring positions of the control parameters $(\mathrm{p}, \mathrm{T})$ and uses the same measuring systems for standard and for non-legislated components.

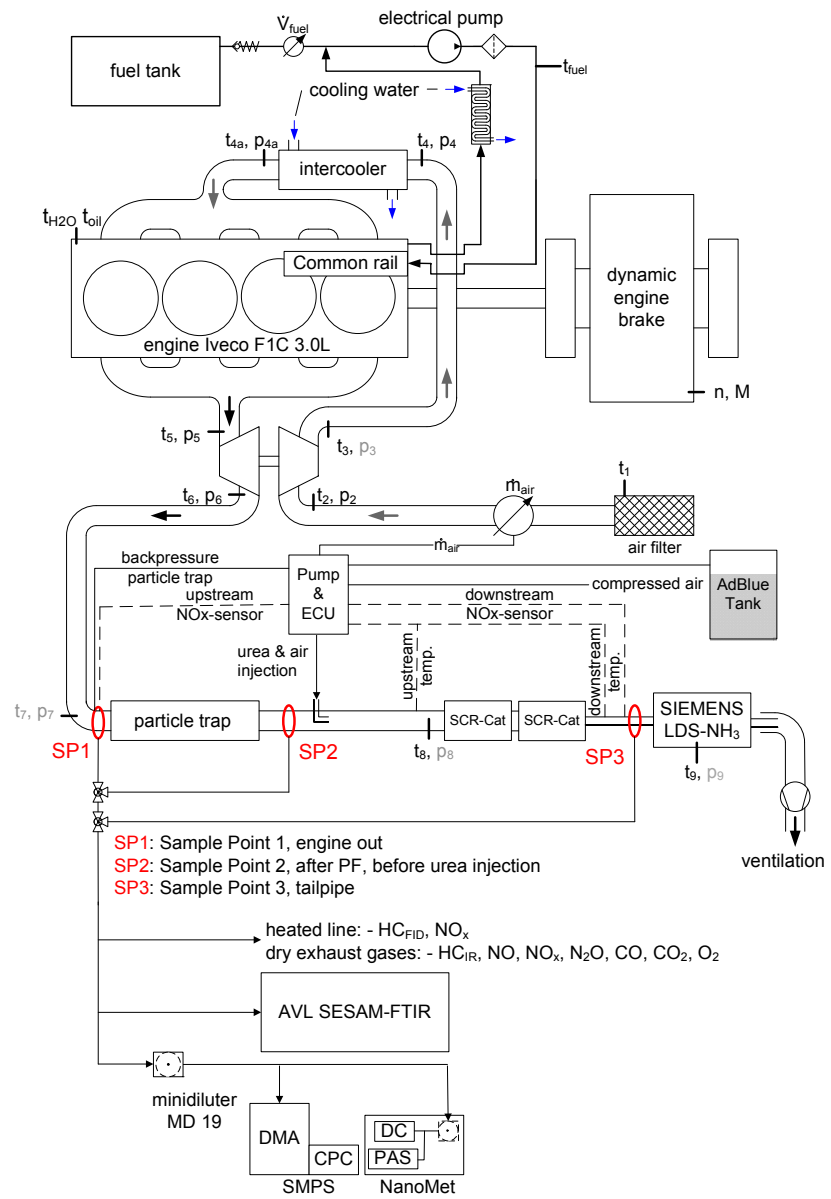

Figure 3 - Engine dynamometer and test equipment for testing of SCR-systems on Iveco engine (engine variant with EGR)

\section{Test equipment for exhaust gas emissions}

Measurements are performed according to the Swiss exhaust gas emissions regulation for heavy duty vehicles (Directive 2005 / 55 / ECE \& ISO 8178):

- Volatile components:

Page 5 of 16
- Horiba exhaust gas measurement devices Type VIA-510 for $\mathrm{CO}_{2}, \mathrm{CO}, \mathrm{HC}_{\mathrm{IR}}, \mathrm{O}_{2}$, Type: CLA-510 for NO, NOx

- Amluk exhaust gas measurement device Type FID 2010 for $\mathrm{HC}_{\mathrm{FID}}$,

- $\mathrm{NH}_{3} \& \mathrm{~N}_{2} \mathrm{O}$ :

With SCR several unlimited components can be produced. The slip of gaseous components: ammonia $\mathrm{NH}_{3}$ and nitrous oxide $\mathrm{N}_{2} \mathrm{O}$ was measured by means of:

- $\quad$ Siemens LDS 6 Laser Analyzer 7MB 6021, $\mathrm{NH}_{3}$

- $\quad$ Siemens ULTRAMAT 6E 7MB2121, $\mathrm{N}_{2} \mathrm{O}$

- Eco physics CLD $822 \mathrm{CM}$ hr with hot line for NO, $\mathrm{NO}_{2}, \mathrm{NO}_{3}, \mathrm{NH}_{3}$.

- $\quad$ FTIR (Fourier Transform Infrared) Spectrometer (AVL SESAM) with possibility of simultaneous, time-resolved measurement of approx. 30 emission components among others: $\mathrm{NO}, \mathrm{NO}_{2}, \mathrm{NO}_{\mathrm{x}}, \mathrm{NH}_{3}, \mathrm{~N}_{2} \mathrm{O}, \mathrm{HCN}, \mathrm{HNCO}$.

\section{Particle counts $\&$ size analysis}

To estimate the filtration efficiency of the DPF, as well as to detect the possible production of secondary nanoparticles, the particle size and counts distributions were analysed with following apparatus:

- $\quad$ SMPS - Scanning Mobility Particle Sizer, TSI (DMA TSI 3071, CPC TSI 3025 A)

- Sample preparation:

- MD19 tunable minidiluter (Matter Eng. MD192E) - heated up to $80^{\circ} \mathrm{C}$

- Thermoconditioner (TC) (i.e. MD19+ postdilution sample heating up to $300^{\circ} \mathrm{C}$ ).

The nanoparticulate measurements were performed at the constant speed (warm) with SMPS. During the dynamic engine operation the CPC was used.

\section{TEST PROCEDURES ON ENGINE DYNOS}

On both engine dynamometers stationary operating points (OP), so called steps-tests were performed. An example is given in Figure 4.

In VERT Filter Test (VFT) generally 4-points tests are used, $[16,17]$.

The VERT secondary emissions tests VSET consist of repetitions of ISO 8-points tests.

In other tests certain OP's were chosen or added according to the research objectives. Particularly to mention is the addition of 3 operating points between OP3 and OP4 to better recognize the urea switch on/off of the SCR-system, $[14,15]$. 
All steps-tests were performed with a warm engine and for each research task always in the same sequence and with the same operating duration of the OP's.

After analyzing the backpressure of the (DPF+SCR) system at stationary operation in the Iveco engine operation map it was decided to limit the operation range, Figure 4. In this limited engine map (LEM) different steps-tests were defined.

With the biofuels,or bio-blend-fuels the calorific value of the fuel changes and so does the full load torque (FL). In the test programs the part load OP's were generally driven with the same power (speed \& torque) and for the FL OP's only the required speed was kept (torque resulted from the fuel). The injection characteristics of the engines were not changed, which represents the usual situation in the market application.

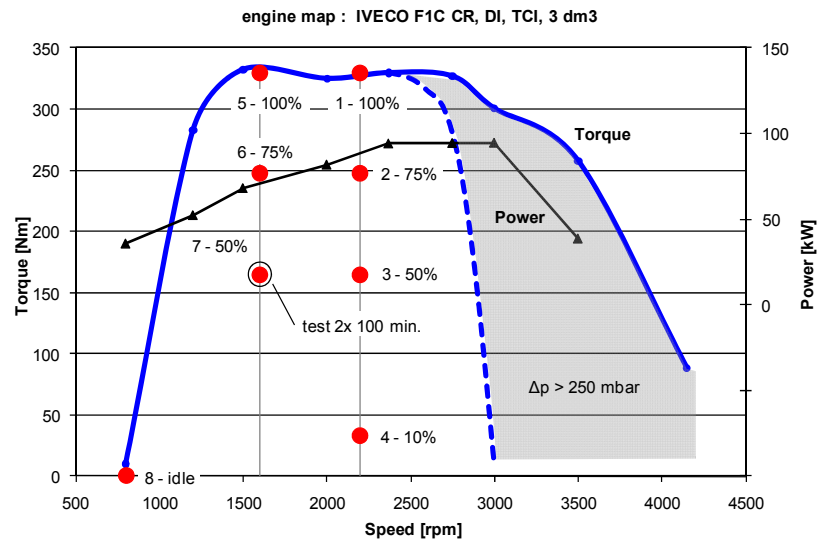

Figure 4 - Limited engine map of the IVECO F1C engine and 8 points test according to ISO 8178

\section{EXHAUST AFTERTREATMENT}

Presented results are obtained with following exhaust aftertreatment devices:

- Diesel oxidation catalyst (DOC, Pt) with catalyzed soot filter $\left(\mathrm{CSF}, \mathrm{SiC}, \mathrm{TiO}_{2}+\mathrm{V}_{2} \mathrm{O}_{5}\right)$ - designated as $(\mathrm{DOC}+\mathrm{CSF})$, or GFM

- $\quad$ CSF alone

- $\quad$ uncoated DPF (for active regenerations, $\mathrm{SiC}$ ) also designated as SFM; (the short names GFM \& SFM are especially useful for the section "DPF anatomy")

- Vanadium based SCR (VSCR)

- combined system: cDPF (Cordierite, Pt) upstream + VSCR downstream.

The used exhaust aftertreatment devices were retrofit parts and they were adapted by the supplier to the size of the engine. In certain cases for frequent research of soot loading and regenerations smaller DPF-units were used and the operating range of the engine was respectively adapted in view of the admissible backpressure.

\section{RESULTS}

\section{Emissions with \& without DPF}

From different test series performed with biofuels with and without DPF a typical example with catalytic DPF (CSF) and with several blending ratios (B0, B7, B20, B30 and B100) was chosen.

The DPF-system (DOC+CSF) was investigated in the VERT 4 pts-test and was used for several tests of regenerations with biofuels.

The comparisons of emissions with different fuel blends and with / without this DPF-system, Figure 5, show:

Without DPF lowering of $\mathrm{CO}, \mathrm{HC}$ and lowering of $\mathrm{PM}$ at high-load OP's with increasing bio-content. The $\mathrm{NO}_{\mathrm{x}}$-values increase with $\mathrm{Bxx}$, which is a fact generally confirmed by the own and foreign research.

With DPF there are: elimination of $\mathrm{CO}$, strong reduction of $\mathrm{HC}$ and an increase of the $\mathrm{NO}_{2} / \mathrm{NO}_{\mathrm{x}}$-ratio. With increasing bio-content this $\mathrm{NO}_{2} / \mathrm{NO}_{\mathrm{x}}$-ratio decreases at part-load OP's. There is a clear catalytic influence of the tested DPF (DOC + CSF).

The investigated DPF shows a very good reduction of particle mass PM.

Fig. 6 shows the comparisons of SMPS PSD-spectra with all fuel blends (except of B7 for graphical clarity) at the high load OP (1100rpm/480 Nm).

There is a tendency (w/o DPF) especially with B100, to emit high PC in nuclei mode (size spectrum below $30 \mathrm{~nm}$ ) and lower PC-concentrations in accumulation mode (30-300 $\mathrm{nm}$ ). With DPF there are also higher PC-concentrations and higher values of penetration with $\mathrm{B} 100$ - more spontaneous condensates.

These tendencies are similar for other OP's and there is also a certain logical sequence of curves with increasing share of biocomponents.

The presented DPF system $(\mathrm{DOC}+\mathrm{CSF})$ was chosen on purpose smaller, than necessary for the research engine to enable a quicker soot loading. Thanks to that it was possible to approach the limit of maximum spacial velocity of this filter, when the NP-blow- through starts to take place. The operating points of the 4 pts. test were adequately set at lower engine speeds $900 \mathrm{rpm}$ and $1100 \mathrm{rpm}$. 


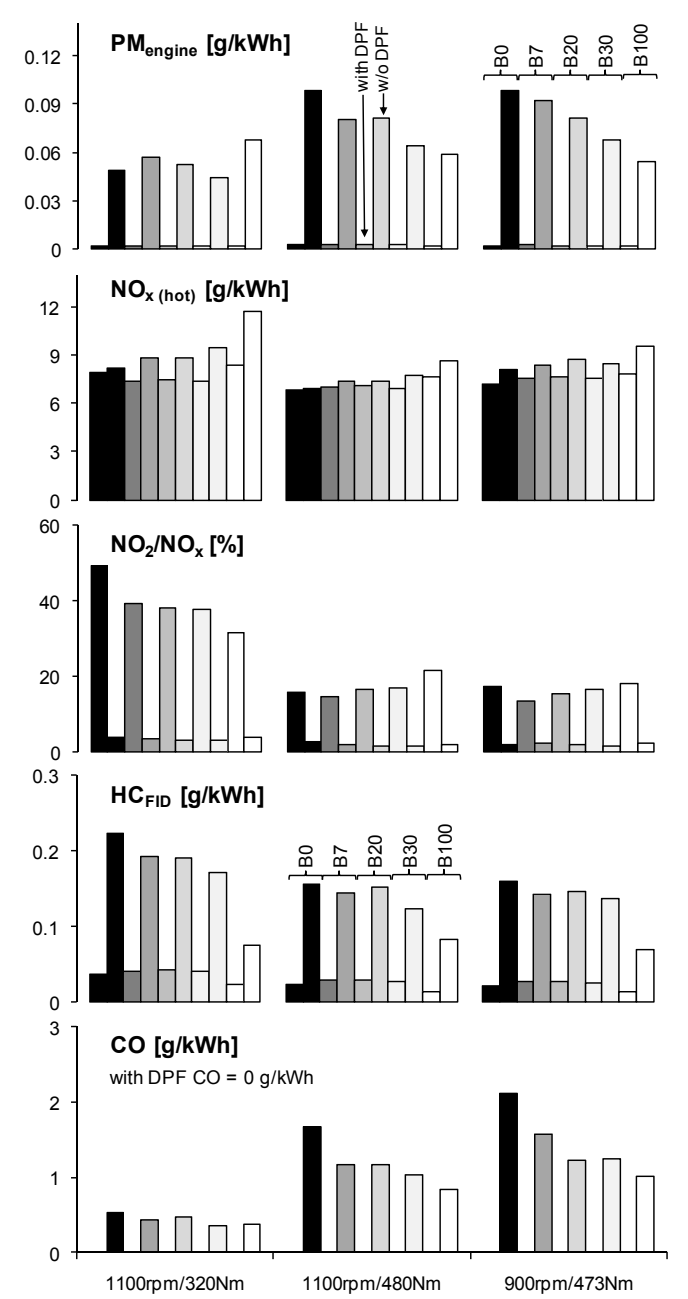

Figure 5 - Comparison of emissions with different fuel blends and with/without DPF-system (DOC+CSF) engine: Liebherr D 934 S

Table 4 summarizes the particle count filtration efficiencies (PCFE) for low and high load OP's. The tendency of a lower filtration efficiency with higher gas flow (higher OP), as well as the tendency of lower filtration efficiency with B100 (more spontaneous post condensation) are confirmed. The filtration material of the investigated DPF fulfills the highest quality requirements of VERT and the requirements of Swiss LRV (OAPC).

Operation above the limit of spacial velocity provokes the NPbreak-through and deteriorates the filtration efficiency PCFE.

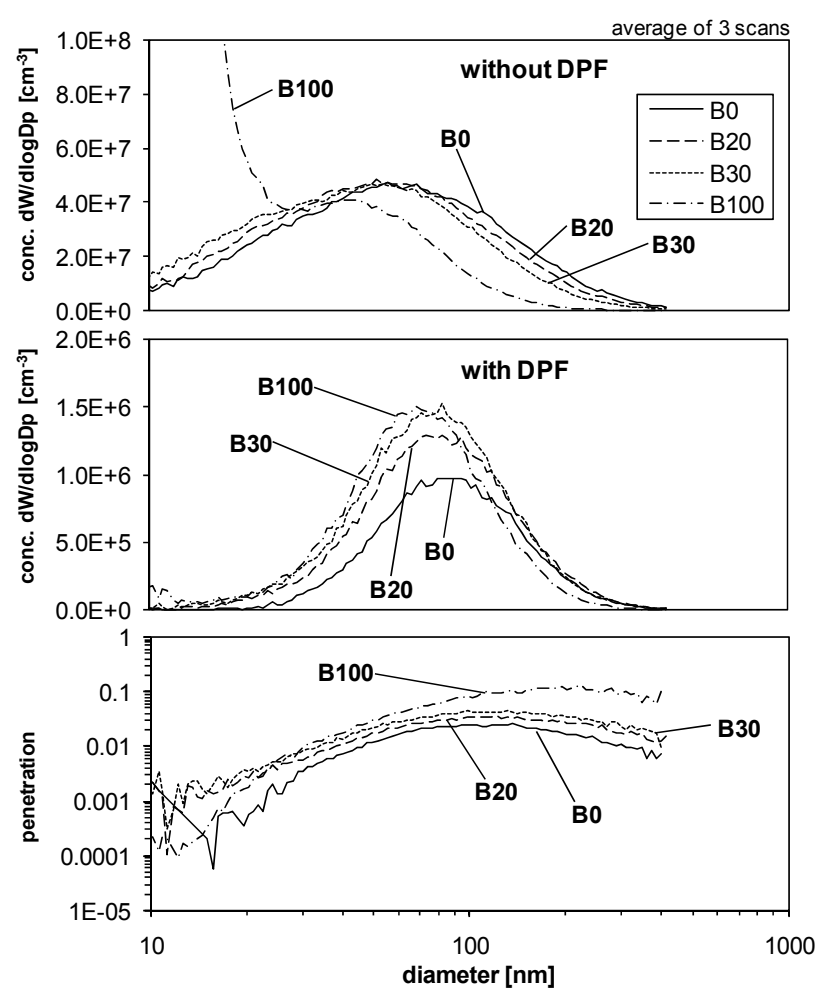

Figure 6 - SMPS PSD - spectra \& penetration values with different fuel blends at (1100rpm/480Nm), with/without DPF coated with DOC, engine: Liebherr D934S

Table 4 - Comparison of trapping efficiencies of counts 20-300 nm (PCFE) with different fuel blends, with / without (DOC+CSF), engine: Liebherr D 934 S; fuels: B0, B7, B20, $B 30$ \& $B 100$

\begin{tabular}{|c|c|c|c|c|c|}
\hline & & \multicolumn{4}{|c|}{ PCFE [\%] } \\
\hline \multicolumn{2}{|c|}{ Operating points } & & & & \\
\hline speed & $\mathrm{rpm}$ & 900 & 900 & 1100 & 1100 \\
\hline torque & $\mathrm{Nm}$ & 473 & 315 & 320 & 480 \\
\hline ulsd & & 98.63 & 99.99 & 100.00 & 98.55 \\
\hline RME7 & & 98.09 & 99.92 & 99.94 & 97.83 \\
\hline RME 20 & & 98.95 & 99.97 & 99.98 & 97.98 \\
\hline RME 30 & & 97.40 & 99.97 & 99.98 & 97.62 \\
\hline RME 100 & & 95.45 & 99.75 & 99.78 & 97.06 \\
\hline
\end{tabular}




\section{Coulometry EC \& OC}

Bio components have an impact on the composition of the particle matter (PM) emitted by the engine.

At the operating points: $1500 \mathrm{rpm} / 10 \%$ and $1500 \mathrm{rpm} / 80 \%$ single samples of particulate matter for coulometry were taken for Diesel and RME (without DPF) on special quarz measuring filters. The coulometric analysis of filter residuum was performed by the SUVA analytical laboratory.

The standard procedure consists of thermal extraction of SOF with $\mathrm{N}_{2}$ at $500^{\circ} \mathrm{C}$ during $8 \mathrm{~min}$ and after that of the ECoxidation with $\mathrm{O}_{2}$ at $650^{\circ} \mathrm{C}$.

Since RME is a fuel, which produces higher portion and heavier SOF, it was decided to increase the temperature of the first thermal $\mathrm{N}_{2}$-extraction to $800^{\circ} \mathrm{C}$ for all samples.

The coulometric results EC, OC \& TC - all values responding to 3 min sampling time on the entire measuring filter and to the same sampling conditions - are represented in Fig. 7.

It can be remarked, that:

- $\quad$ higher engine load produces less OC and more EC, i.e. "dryer" soot

- RME causes higher portion of OC (lower portion of EC), which is particularly pronounced at lower engine load

- RME reduces the total PM at higher engine load, especially due to the reduction of EC.
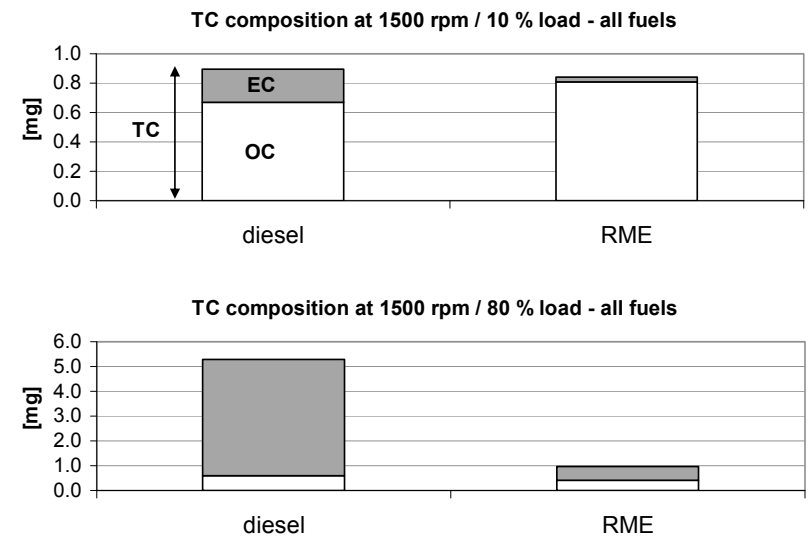

Figure 7 - Influences of engine load on EC/TC-ratio for different fuels

\section{Passive Regenerations}

The results of soot loading procedures give important information about the effects of biocomponents.

The soot loading of the DPF's was performed up to $\Delta \mathrm{p} \approx 100$ by means of a rectangular cycle $0-500 \mathrm{Nm} \& 800-1100 \mathrm{rpm}$, which was the best compromise to produce PM without, or with minimum passive regeneration.

Page 8 of 16
All loading procedures, except of B100, were performed in identical way. For B100, which yielded very slow soot loading, periodical switch-off's of the engine were applied to cool-down the exhaust system and to minimize the oxidation.

The soot loading with increased bio-content needed always a longer time period. This is represented for $(\mathrm{DOC}+\mathrm{CSF})$ and for CSF in Figure 8.

The final particle mass, as product of engine-out emission and time, increases. Nevertheless the oxidized portion of PM during the soot loading procedure and the PM remaining in the DPF at the end of the soot loading procedure are unknown.

The reasons for slower soot charging with biocomponents are:

- lower engine-out PM-emissions,

- $\quad$ higher reactivity of PM and partial oxidation during soot loading with DOC,

- $\quad$ with high bio-content (here B100) reaching of exhaust gas temperature, which is nearer to the temperature-window of the highest $\mathrm{NO}_{2}$-production in DOC, easier $\mathrm{NO}-\mathrm{NO}_{2}$ oxidation with $\mathrm{B} 100$ and the intensified $\mathrm{NO}_{2}$-continuous regeneration.
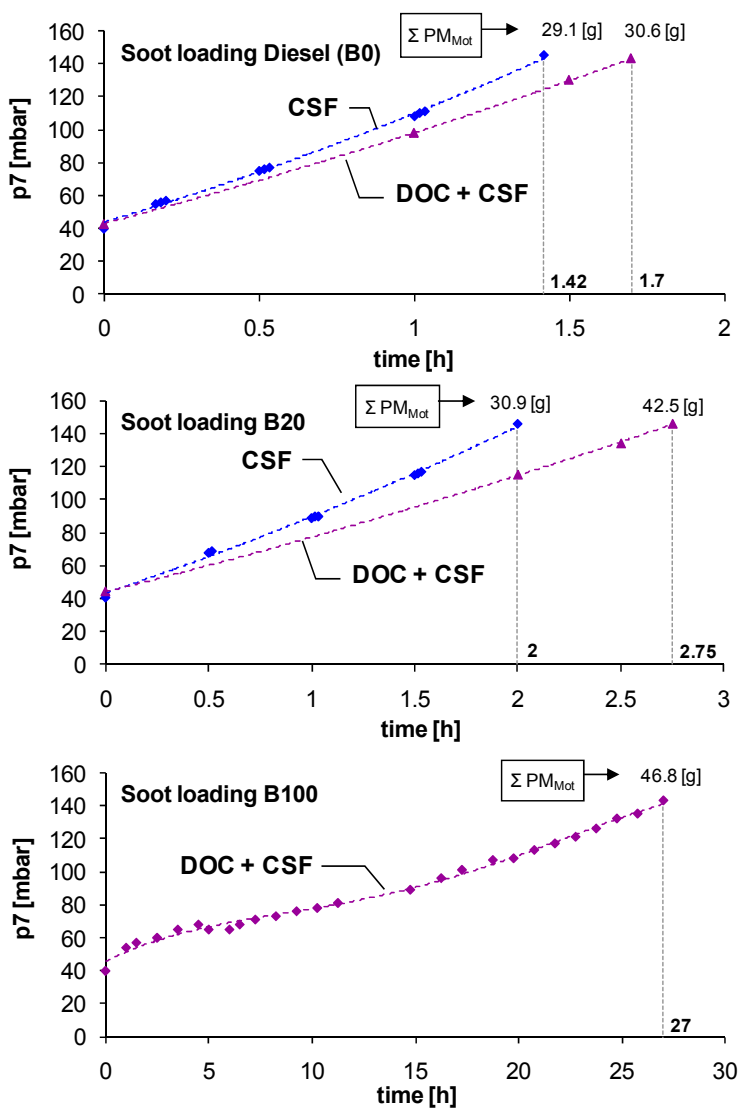

Figure 8 - Backpressure during soot loading cycle 
After the soot loading each regeneration attempt was performed in the same way: stepwise increasing of engine torque at a constant speed.

In Figure 9- the comparison of regenerations 7, $11 \& 10$ (B0, B20 \& B100 with DOC + CSF) shows with B100 following tendencies, which would not be visible with B20:

- there is more $\mathrm{NO}_{2}$ with $\mathrm{B} 100$ with a peculiar $\mathrm{NO}_{2}$ generation behaviour in the subsequent load steps,

- the intensity of regeneration with B100 from $5^{\text {th }}$ step (approx. $300^{\circ} \mathrm{C}$ ) is higher; the drop of backpressure quicker than with the other fuels,

- with B100 the $\mathrm{N}_{2} \mathrm{O}$ peak in $2^{\text {nd }}$ step is a little bit higher, than with $\mathrm{B} 20(7 \mathrm{ppm} / 5 \mathrm{ppm})$ and after start of regeneration $\mathrm{NH}_{3}$ is produced with $\mathrm{B} 100$ up to $6 \mathrm{ppm}$ (during $1 / 2 \mathrm{~h}$ ), while with B20 it stays at zero-level; all this confirms the increased ractivity of B100.

The specific $\mathrm{NO}_{2}$ production with $\mathrm{B} 100$ was confirmed with all used measuring systems and the authors explain it with the combination of different effects:

- the exhaust temperature with B100 is lower i.e. nearer to the range of the maximum of $\mathrm{NO}_{2}$ production; the authors believe, that due to the general higher reactivity of B100-exhaust components, the temperature window of $\mathrm{NO}_{2}$ production is larger,

- there is more $\mathrm{NO}_{\mathrm{x}}$ with B100 (up to $20 \%$ - not plottet here),

- $\quad$ there is more easy NO-NO2 oxidation,

- in the steps $5 \& 6$ there is the most pronounced backpressure drop with B100, which means that most of the soot was burned away,

- $\quad$ in the further steps $7,8 \& 9$ periodical effects are observed:

a) shortly after load increase $\mathrm{NO}_{2}$ decreases because of higher spatial velocity and shortly increased availability of more $\mathrm{PM}$ and $\mathrm{NO}_{2}$ - consumption for oxidation. In this period the $\mathrm{NO}$ and $\mathrm{NH}_{3}$ increase,

b) in further part of the load step the DPF attains the new thermal equilibrium the $\mathrm{NO}_{2}$ starts to increase and $\mathrm{NH}_{3}$ decreases. $\mathrm{NO}_{2}$ and $\mathrm{NH}_{3}$ are anti-correlated,

c) the slight generation of $\mathrm{NH}_{3}$ is possible from $\mathrm{NO}$ \& $\mathrm{H}_{2} \mathrm{O}$ due to the increased reactivity of $\mathrm{B} 100-$ exhaust gases.

To deepen, or to confirm the demonstrated reaction mechanizms more research would be necessary.

Nevertheless the authors are sure to have demonstrated an important and specific feature of emissions with B100.
Table 5 summarizes the domains of temperatures when the start of backpressure drop is visible in the investigated regeneration variants. There are higher temperatures necessary with less catalytic activity and they decrease with growing bio-content in fuel.
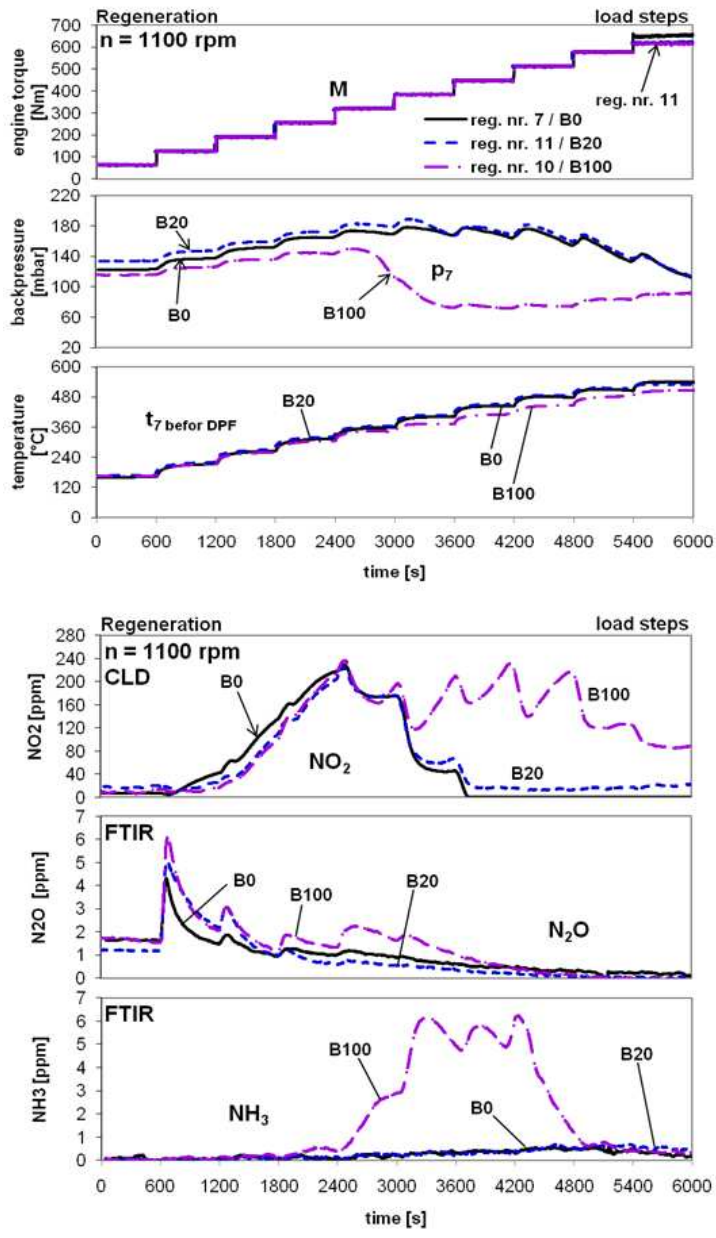

Figure 9 - Regenerations with $(\mathrm{DOC}+\mathrm{CSF}) \&$ $B 0, B 20 \& B 100$

Table 5 - Domains of temperatures with the beginning backpressure drop of the investigated regeneration cases

\begin{tabular}{|l|l|l|}
\hline \multicolumn{3}{|c|}{ DOC + CSF } \\
\hline B0 & B20 & B100 \\
\hline $356-368^{\circ} \mathrm{C}$ & $356-363^{\circ} \mathrm{C}$ & $342^{\circ} \mathrm{C}$ \\
\hline at step 5 & at step 5 & at step 5 \\
\hline \multicolumn{3}{|c|}{ CSF } \\
\hline B0 & B20 \\
\hline $454-464^{\circ} \mathrm{C}$ & $447-455^{\circ} \mathrm{C}$ \\
\hline at step 7 & at step 7 \\
\hline
\end{tabular}




\section{DPF anatomy}

Some DPF substrates, which were operated only with one sort of fuel (each one) were cut at EMPA Laboratories and analysed for composition and distribution of soot and ashes.

Each substrate, except of B100, experienced 3 soot loadings (up to $\Delta \mathrm{p}=100 \mathrm{mbar}$ ) and regenerations before being cut for the analysis. With B100 the substrates were charged only once. The uncoated substrate (SFM) accumulated so much combustible PM with high heat value, that the DPF was overheated and damaged during the regeneration attempts. This substrate was cut after this trial and was not used for any other tests.

Macroscopic and scanning electron microscope (SEM), as well as transmission electron microscope (TEM) and X-Ray diffraction studies were carried out to investigate the nature and properties of particulate matter (PM) deposited in six diesel particulate filters (DPFs) made of $\mathrm{SiC}$ and operating with the same HD engine (Liebherr D 934 S) as follows: with $100 \%$ rapeseed methyl ester (RME) biofuel (B100), diesel fuel (B0) and a blend of 20\% RME and 80\% diesel (B20). Three out of the six DPFs (named hereafter GFM) were catalytically coated with $\mathrm{TiO}_{2} / \mathrm{V}_{2} \mathrm{O}_{5}$, the other three (named hereafter SFM) were uncoated. The investigated PM deposits were either extracted from sectioned DPF channels or studied 'in situ', as deposited.

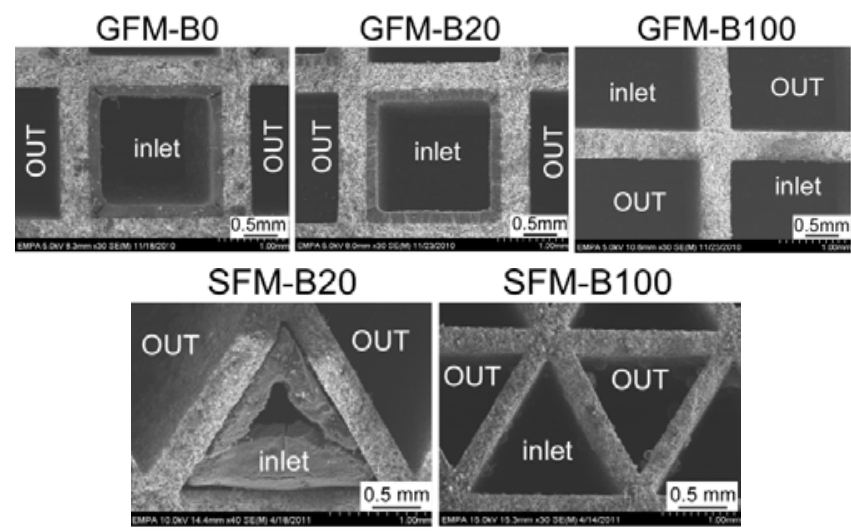

Figure 10 - Scanning electron microscope SEM representative images of inlet and outlet (OUT) channels of the GFM- and SFM-DPFs showing a soot cake deposited on the inlet channels of the GFM-B0-DPF, the GFM-B20- and SFM-B20-DPFs. The B100-DPFs show no soot cake deposition on the channel walls.

The B100-DPFs show very little soot deposition, opposite to B20 and B0 which exhibit abundant soot deposits. This observation applies for both GFM and SFM types of DPFs. Soot in all three GFM-DPFs, as well as in SFM-B20 and SFM-B0 forms a cake deposited on the inlet channel walls (Fig. 10). In GFM-B100, the soot cake is thinnest or nonexisting. The soot cake deposited on the GFM-B100-DPF cannot hold, at some stage, on the walls of the channels, Page 10 of 16 probably because of the nature and amount of the underlying material composed of ash and other particle components. The latter are related to the catalytic coating material and/or to fibrous material mechanically transported from the inlet gasket and the intumescing mat enveloping the DPF-DOC assembly.

Based on TEM imaging, the average size of the individual soot particles in GFM-B100 is $21 \mathrm{~nm}$ (mean value of 101 measurements) with minimum and maximum values of $11 \mathrm{~nm}$ and $38 \mathrm{~nm}$, comparable and rather on the low side in relation to pure diesel soot. Preliminary results of high resolution (HRTEM) images depicting the internal nanostructure of the primary particles of GFM-B100 soot indicate a relatively higher oxidative reactivity compared to diesel soot, a feature described also in previous research studies.

It is recalled that, based on a series of TEM studies (e.g. [9, 10]), the more amorphous the internal nanostructures of primary soot particles the more easily they can be oxidized. Moreover, smaller particles show higher response to oxidation (due to higher surface to volume ratio) than larger ones.

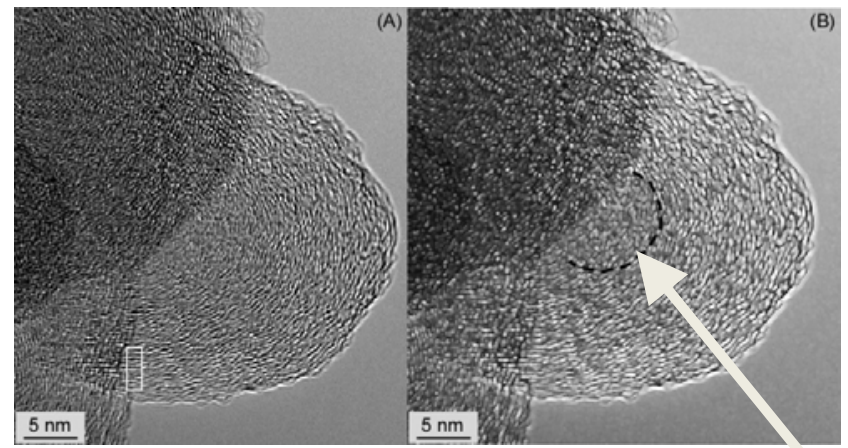

More amorphous structure (higher oxidative reactivity)

Figure 11 - HRTEM images of a representative soot particle from the GFM-B100-DPF. In (B) the image is processed in 'Photoshop' to render the fringes arrangement more discernible. The dashed line marks the particle core with a more amorphous structure.

Locally, a higher degree of crystalline order is observed by regular repetition of graphenes (up to 10 alternating layers in 1-2 $\mathrm{nm}$ wide packages) in a crystalline (graphite-like) structure (white rectangle in Figure 11A). Based on macroscopic, as well as optical microscopic and SEM observations on a series of samples from the dissected DPFs, the B100DPFs contain significantly more ash compared to B20 and B0 implying that besides lubricating oil, RME-biofuel is the major contributor of ash production. This observation is more pronounced with the GFM-B100-DPF type, probably because the extremely high temperatures experienced by the SFMB100-DPF obscured the original PM deposition material in this filter. In the B0- and B20-DPFs of both GFM and SFM types, ash occurs onto the channel walls underneath the soot cake. Ash is found on the channel walls of GFM-B100-DPF implying that it occurred also underneath the thinner soot 
cake, at the time when this was deposited on the channel walls.

Newly formed V-O-bearing long prismatic nanocrystals occur in abundance within fissures of the catalytic coating layer, as well as onto the coating layer surface in both inlet and outlet channels of all three GFM-DPFs. Their size and shape is such that they can escape to the ambient air.

Al-Si-O-, as well as Ca-Al-Si-O-fibres deriving from the gasket on the outer inlet surface of the DPF and the intumescing mat, respectively, occur inside all six DPFs, often mechanically mixed with ash. In the overheated SFM-B100, the Ca-Al-Si-O-fibres are locally molten forming droplet-like to spherical formations.

Based on SEM imaging and qualitative energy dispersive Xray analyses (EDX), the material underlying the soot cake in the three GFM-DPFs, which are catalytically coated, consists of ash $(\mathrm{Ca}, \mathrm{S}, \mathrm{P}, \mathrm{O}, \mathrm{Mg}, \mathrm{K})$, catalytic coating material and its reaction $\mathrm{V}-\mathrm{O}$-long prismatic crystal products, as well as gasket $(\mathrm{Al}, \mathrm{Si}, \mathrm{O})$ and intumescing mat $(\mathrm{Ca}, \mathrm{Al}, \mathrm{Si}, \mathrm{O})$ fibres. In the SFM-DPFs, the deposition material other than soot consists of ash (Ca, P, S, Zn, Si, Mg, K, Al, V, Y, O), gasket (Al, Si, O), as well as intumescing mat $(\mathrm{Ca}, \mathrm{Al}, \mathrm{Si}, \mathrm{O})$ fibres.

Needle-like to worm-like formations consisting mainly of $\mathrm{Si}$ and occasionally variable amounts of $\mathrm{Al}, \mathrm{O}, \mathrm{C}$ occur attached to the filter wall material of all three SFM-DPFs. Their formation may be related rather to the $\mathrm{SiC}$ wall material. In the SFM-B100-DPF, which has locally seen very high temperatures $\left(>1200{ }^{\circ} \mathrm{C}\right)$, both filter material, as well as deposited ash PM and intumescing mat melted, at least partly. The filter material gave rise to new fibrous, platy and spherical particles of $\mathrm{SiC}$ composition.

\section{Secondary emissions and traces (whole exhaust at tailpipe)}

Secondary emissions and traces are investigated as a part of VERT / LRV quality verification procedure for DPF- and SCR-systems. The sampling and analytics are performed by a specialized team of EMPA Analytical Laboratory for Organic Chemistry. There are 3 groups of secondary emissions, which are known as very carcinogen and toxic:

- Polycyclic Aromatic Hydrocarbons PAH, 12 substances $\left.{ }^{*}\right),[\mu \mathrm{g} / \mathrm{L}]$,

- $\quad$ Nitro-PAH, 22 substances ${ }^{*}$ ), [ $\left.\mu \mathrm{g} / \mathrm{L}\right]$,

- Polychlorinated Dibenzodioxins PCDD and Polychlorinated Dibenzofurans PCDF, 33 substances ${ }^{*}$, $[\mathrm{pg} / \mathrm{L}]$.

A VERT Secondary Emissions Test was performed with biofuels B100 and B30 and with urea based SCR as well as with combinations of SCR and biofuels (without DPF).
Samples were taken continuously proportional to the actual gas flow (aliquot) from the undiluted hot exhaust gas. A volume of typically 5-8 Nm3 was collected through a validated sampling arrangement over 200 Minutes driving cycle time (2 full ISO 8178/4 C1-cycles).

The sampling device consists of a sampling sonde, cooler, condensate separator, filter stage and two-stage adsorber unit (XAD-2). The sampling apparatus, made from glass is extensively cleaned and heated to high temperatures prior to each sampling (heating in steps up to $450^{\circ} \mathrm{C}$ ). Using marked PCDD-standards in this investigation the recovery was found to be $65 \pm 10 \%$.

The same sample was used to determine the PCDD/F as well as the PAH.

PCDD/F-analysis was performed by separating the toxicologically relevant $\mathrm{PCDD} / \mathrm{F}$ isomers using gas chromatography followed by high resolution mass spectrometry.

After chromatographic work-up quantitative analysis of the PAH and Nitro-PAH were also performed using capillary gas chromatography high resolution mass spectrometry.

\section{$\underline{\text { PCDD/F-Analysis }}$}

The following graph, Figure 12, shows the overall results.

There seems to be a slight indication of increase when biofuels are used without SCR. This is more pronounced with some individual compounds like the Seveso Dioxin. When SCR is used these toxic substances are clearly reduced with both fuels.

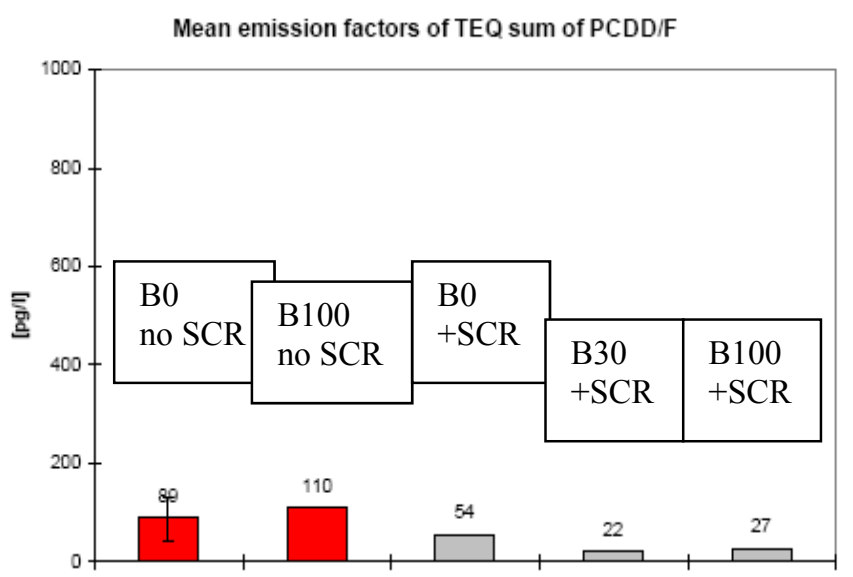

Figure 12 - Emission factors for the weighed sum of 2, 3, 7, 8 -substituted PCDD/F (TEQ-sum) in pg per liter fuel, Iveco F1C E3.

\footnotetext{
${ }^{*}$ analyzed in presented tests
} 


\section{PAH-Analysis:}

PAH were analysed from the same sample as the PCDD/F. The following graph, Fig. 13, summarizing the data for the carcinogenic PAH according to the IARC-definition shows the overall results.

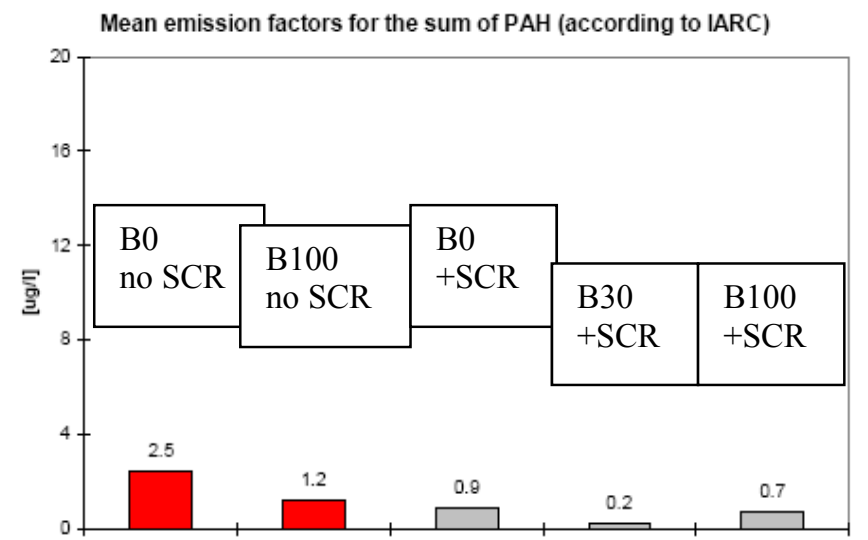

Figure 13 - Emission factors for the sum of carcinogenic $P A H(I A R C)$ in $\mu g$ per liter fuel, Iveco F1C E3.

It can be summarized, that:

- Biofuels B100 and B30 had little influence on $\mathrm{NO}_{\mathrm{x}}$, $\mathrm{NO}_{2} / \mathrm{NO}_{\mathrm{x}}, \mathrm{CO}, \mathrm{CO}_{2}$ and consumption of fuel, however they reduced $\mathrm{HC}$ by about $50 \%$, PAH by $52-78 \% \%$ and Nitro-PAH by $50-70 \%$

- The Urea based SCR reduced $\mathrm{NO}_{\mathrm{x}}$ on average by about $85 \%$ and eliminated $\mathrm{NO}_{2}$

- SCR also reduced HC, PAH and Nitro-PAH very effectively but had no influence on $\mathrm{CO}$

- The side effects of the SCR technology can be emissions of $\mathrm{NH}_{3}, \mathrm{~N}_{2} \mathrm{O}$ and $\mathrm{HNCO}$. These were visible but not very pronounced

- Formation of dioxines and furanes was visible but not promoted by these technologies

- The combination of SCR and biofuels had no negative side effects - on the opposite a further reduction of PAH and $\mathrm{PCDD} / \mathrm{F}$ could be observed.

\section{DOC light-off with biocomponents}

In order to investigate the DOC light-off load steps were performed at different engine speeds (900, $1100 \& 1300 \mathrm{rpm})$ with B0, B20 \& B100. These load steps with 5 min step duration were conducted up and down to see the possible effects of hysteresis.

Following findings can be pointed out:

With increased bio-content there is a higher $\mathrm{NO}_{\mathrm{x}}$ - and lower HC-emission.

During the load jump from the $1^{\text {st }}$ to the $2^{\text {nd }}$ step, there are:

Page 12 of 16
- elimination of $\mathrm{CO}$, equal for all fuels,

- lowering of $\mathrm{HC}$ with B100, while increasing with B0 in the 2 minutes after load jump - most probably due to the starting oxidation of HC with B100, (CO \& HC not demonstrated here),

- quicker increase of $\mathrm{NO}_{2}$ with $\mathrm{B} 100$ which indicates an easier light-off with B100.

Similar tendencies are also visible with B100 at higher engine speeds.

The differences are less pronounced due to higher flow velocities through the catalyst.

The representation in function of exhaust temperature, Fig. 14, confirms that there is light-off for $\mathrm{NO}_{2}$ starting with $\mathrm{B} 0$ at approx. $220^{\circ} \mathrm{C}$, with $\mathrm{B} 20$ at $200^{\circ} \mathrm{C}$ and with $\mathrm{B} 100$ at $170^{\circ} \mathrm{C}$.

For $\mathrm{HC}$ the lowering in the $1^{\text {st }}$ step with $\mathrm{B} 100$ is confirmed, which indicates the light-off for $\mathrm{HC}$ at approx. $170^{\circ} \mathrm{C}$. (As light-off in this context the visible start of reaction is understood).

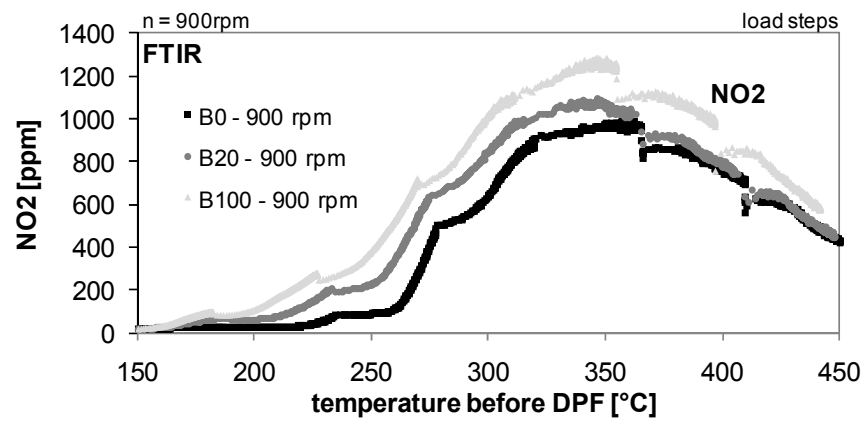
Figure 14 - Influences of fuels B0, B20 \& B100 on DOC
light-off for $\mathrm{NO}_{2}$ in steps tests; Liebherr D $934 \mathrm{~S} \mathrm{A6}$

The consideration of $\mathrm{NO}_{2}$ - and $\mathrm{HC}$-plots in function of exhaust gas temperature at increasing engine speed, allows to remark, that there is a little influence of increasing gas flow and increasing spacial velocity (SV) on the light-off. With higher engine speed the start of increasing $\mathrm{NO}_{2}$, or decreasing $\mathrm{HC}$ is moved to higher exhaust gas temperature (in the range of $\Delta \mathrm{t} \approx 10^{\circ} \mathrm{C}$ ).

With the chosen duration of steps ( $5 \mathrm{~min}$ ) there were differences of results between the tests with increasing or decreasing load.

It can be generally remarked, that during the down-steps there is higher temperature level, which causes the more intense catalytic conversion of $\mathrm{CO}, \mathrm{HC} \& \mathrm{NO}_{2}$ in the lower steps. These temperature differences caused by different ways of conducting the tests are due to the thermal inertia of the system.

The resulting statement is that the results in all steps tests (like ISO 8178 , or ESC) are connected to the time-schedule of the test procedure. 


\section{PAH \& TEQ of particle mass with biofuels}

Particle matter (PM) emitted by the engine at different operating points (OP), with different fuels (B0, B30 \& B100) and with different exhaust gas aftertreatment was sampled and analyzed at the JRC laboratories.

14 Polycyclic Aromatic Hydrocarbons (PAH) were determined in the filter samples by means of the High Pressure Liquid Chromatography (HPLC) and the toxicity equivalence (TEQ) according to the EPA method was estimated.

The analyzed PAH and their toxicity equivalence factors are represented in the following Table 6:

\section{Table 6 - Toxicity equivalence factors of different PAH's (according to US EPA 1994)}

\begin{tabular}{ll}
\hline Compound & TEF \\
\hline Fluorene & 0,001 \\
Phenanthrene & 0,001 \\
Anthracene & 0,001 \\
Fluoranthene & 0,010 \\
Pyrene & 0,001 \\
Benzo[a]anthracene & 0,100 \\
Chrysene & 0,010 \\
Benzo[b]fluoranthene & 0,100 \\
Benzo[k]fluoranthene & 0,100 \\
Benzo[e]pyrene & 0,002 \\
Benzo[a]pyrene & 1,000 \\
Indeno[1,2,3-CD]pyrene & 0,100 \\
Dibenz[a.h]anthracene & 1,000 \\
Benzo[ghi]perylene & 0,010 \\
Coronene & 0,010
\end{tabular}

Particle matter was sampled on the Iveco F1C engine at a part load (PL) and full load (FL) operating points with different exhaust aftertreatment systems according to the following matrix:

\begin{tabular}{|l|l|l|c|}
\cline { 2 - 4 } \multicolumn{1}{c|}{} & \multicolumn{1}{c|}{ B0 } & B30 & B100 \\
\hline w/o aftertreatment & PL / FL & PL / FL & PL / FL \\
\hline DPF + SCR & PL / FL & PL / FL & PL / FL \\
\hline SCR only & PL / FL & PL / FL & PL / FL \\
\hline
\end{tabular}

PL (part load): $2200 \mathrm{rpm} / 32 \mathrm{Nm}$

OP4, $7.4 \mathrm{~kW}$

FL (full load): $2200 \mathrm{rpm} / 300-330 \mathrm{Nm}$

OP1, $74 \mathrm{~kW}$

The comparison of TEQ in [ng / mg PM] for all investigated variants of fuel, of aftertreatment and operating points is represented in Fig. 15.
It can be remarked:

- there is generally a lower TEQ at higher OP1,

- with increased bio-content there is a tendency of lovering TEQ at lower OP4 and of increasing TEQ at higher OP1; (some exceptions - especially SCR B0 \& SCR B30 at OP4 - are attributed to the measuring and emitting dispersion),

- the SCR alone produces at low load generally higher TEQ as (DPF+SCR),

- at high load with higher bio-content the TEQ of (DPF + SCR) is higher, than of SCR alone - this can be attributed to the condensation effects after DPF, which are promoted by the presence of bio-components and a seeding effect of the secondary NP from SCR.

The view on TEQ-comparisons in [ $\mu \mathrm{g} / \mathrm{kWh}$, (not represented here), allows further statements:

- SCR has a tendency to slightly lower the TEQ-values, comparing with no aftertreatment,

- $\mathrm{DPF}$ is the best method to eliminate PAH and to minimize TEQ.

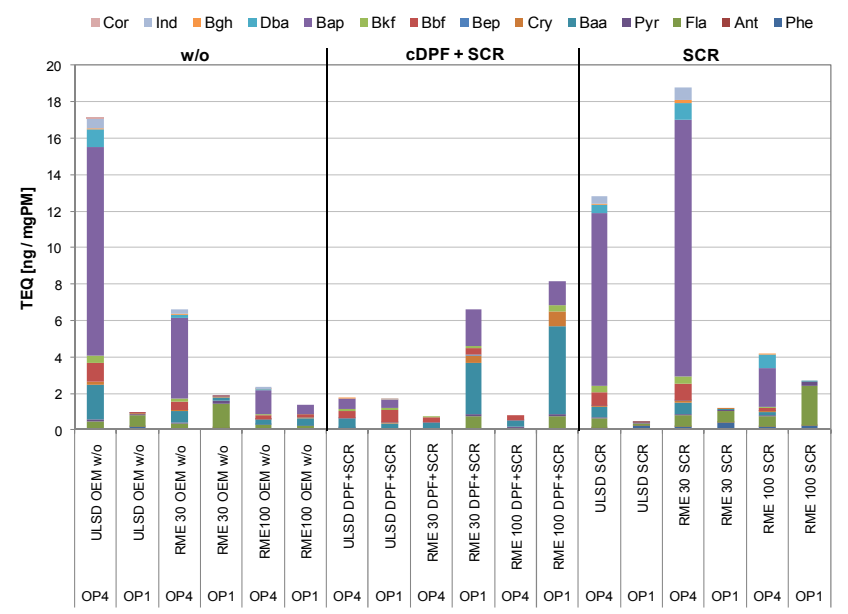

Figure 15 - Toxicity Equivalence TEQ [ng / mgPM] with biocomponents (RME), SCR and DPF, Iveco F1C E3

\section{CONCLUSIONS}

The most important conclusions, according to the investigated topics and the performed working packages, can be listed as follows:

\section{Emissions with \& without DPF}

- $\quad \mathrm{RME}$ lowers $\mathrm{CO}$ and $\mathrm{HC}$ and increases $\mathrm{NO}_{\mathrm{x}}$ at all operating points, it lowers PM at higher engine loads and increases PM at lower engine loads. RME has no effect on specific energy consumption. 
- $\quad$ RME moves the PSD spectra to smaller sizes and increases the nuclei mode due to spontaneous condensates,

- with $\mathrm{RME}$ there is a higher portion of condensates (SOF) at low load and idling,

- $\quad$ RME causes higher portion of OC (lower portion of EC), which is particularly pronounced at lower engine load,

- RME reduces the total PM at higher engine load, especially due to the reduction of EC,

- with (DOC + CSF) there is a clear catalytic influence: elimination of $\mathrm{CO}$, strong reduction of $\mathrm{HC}$ and increase of the $\mathrm{NO}_{2} / \mathrm{NO}_{\mathrm{x}}$-ratio,

- the tested DPF reaches the nanoparticle counts filtration efficiency PCFE up to $99.99 \%$,

- using of pure biofuel B100 also lowers the PCFE due to post condensation effects and increased penetration of smallest particles, except of that the lower blends (B7, B20 \& B30) have no impact on PCFE.

\section{Regenerations with (DOC+CSF)}

- with the same soot loading procedure the necessary time to load the DPF for $\Delta \mathrm{p}=$ idem increases with the biocontent of fuel (here for $\Delta \mathrm{p} \approx 100$ mbar: B0 1,7h; B20 2,5h; B100 27h),

- the reasons for slower soot charging with biocomponents are:

- lower engine-out PM-emissions,

- higher reactivity of $\mathrm{PM}$ and partial oxidation during soot loading with DOC,

$\circ$ with high bio-content (here B100) lowering of exhaust gas temperature to the temperature-window of the highest $\mathrm{NO}_{2}$-production in DOC, easier NO$\mathrm{NO}_{2}$ oxidation with $\mathrm{B} 100$ and the intensified $\mathrm{NO}_{2}$ continuous regeneration.

\section{DPF anatomy}

- with RME blend fuels more amorphous (reactive) structures of soot are remarkable,

- with higher RME portion there is less soot deposited in the filter, but there are more elements creating ashes, like: $\mathrm{Zn}, \mathrm{Mg}, \mathrm{Ca}, \mathrm{K}, \mathrm{Si}, \mathrm{P}, \mathrm{S}$.

\section{Secondary emissions traces with SCR \& RME}

- Biofuels B100 and B30 reduced $\mathrm{HC}$ by about $50 \%$, PAH by $52-78 \% \%$ and Nitro-PAH by $50-70 \%$

- SCR reduced HC, PAH and Nitro-PAH very effectively but had no influence on $\mathrm{CO}$

- The combination of SCR and biofuels had no negative side effects - on the opposite a further reduction of PAH and $\mathrm{PCDD} / \mathrm{F}$ could be observed.

\section{DOC light-off with biocomponents}

- due to the higher reactivity of RME the fuels with higher bio-content cause an easier light-off of the DOC,

- with $\mathrm{B} 100$ the $\mathrm{NO}-\mathrm{NO}_{2}$-oxidation and the $\mathrm{HC}$-conversion start already at approx. $170^{\circ} \mathrm{C}$,

- with higher engine speed (higher spacial velocity) the start of increasing $\mathrm{NO}_{2}$, or decreasing $\mathrm{HC}$ is moved to higher exhaust gas temperature (here $\Delta \mathrm{t} \approx 10^{\circ} \mathrm{C}$ ),

- due to the thermal inertia of the engine-exhaust-system there are differences of emission results by conducting the steps test with increasing or with decreasing engine load,

- the emissions results in all steps tests are connected to the time-schedule of the test procedure.

\section{PAH \& TEQ of the PM with biofuels}

- DPF has a positive effect of reducing PAH \& TEQ of the PM,

- at low-load operating conditions without DPF there is a tendency of higher TEQ (due to presence of $\mathrm{B}(\mathrm{a}) \mathrm{P}$ ),

- higher biofuel content has with DPF no influence on TEQ,

- without DPF there is a tendency of lowering TEQ at low load and increasing TEQ at high load,

- no differences concerning TEQ could be remarked for catalytic and non-catalytic DPF's; this result nevertheless must be limited to the present engine and the present operating conditions,

- $\quad$ SCR alone has no influence on TEQ.

\section{REMARKS \& RECOMMENDATIONS}

The present investigations did not concern the long term effects:

- $\quad$ possible coinfluences of bio-fuels with lubricating oil,

- possible deactivation of catalytic activity in case of too high content of sulphur, phosphorus and dirt if the biofuel quality does not correspond to the actual norms,

- possible influences on deposits and material degradation in fuel system, in combustion chambers and in the exhaust aftertreatment of the engine.

The fulfilment of biofuel quality requirements depends on supplier, transport, stocks conditions and time of storage.

Biocomponents have limited durability (validity) time because of oxidative degradation, water absorption and possible bacteria befall $[18,19,20]$. For these reasons the user of biofuel is recommend to periodically control the quality of supply chain and of the fuel.

A recently published study of a US industrial consortium, [21], about the impact of biodiesel impurities on the long-term 
behaviour of exhaust aftertreatment elements showed, that due to diffusion of Alcali Metals $(\mathrm{K}, \mathrm{Na}, \mathrm{Ca})$ into the ceramic materials of DOC, DPF and SCR, the material resistance of these elements is reduced significantly during the long duration operation.

Following recommendations can be given for the use of biofuels with DPF systems:

- the filtration efficiency is not influenced by the biofuel, but there can be artefacts of spontaneous condensates after DPF,

- performing filtration quality tests, like is recommended with a standard fuel,

- for long life of catalytic coatings and for sustainable engine operation control periodically the quality of fuel and fuel supply chain,

- consider the general recommendation for the engine: durability of injection system and of lube oil; power reduction with fuels with lower heat value; limits of electronic regulation with changed heat value of fuel.

The recommendations for the users of SCR systems with biofuels concern the fuel quality and the sustainability of the engine operation and are the same, as mentioned above for DPF.

Generally plan more frequent oil change and inspection/maintenance intervals.

\section{ACKNOWLEDGEMENTS}

The authors thank the Swiss Federal Offices for Environment and for Energy and the Swissoil for the financial support of the project.

The participation and material contributions of the industrial partners: DINEX, DK; HUG AG, CH and HUSS GmbH, D are highly appreciated.

Contact: Prof. Dr. J. Czerwinski, AFHB, www.afhb.bfh.ch, jan.czerwinski@bfh.ch

\section{REFERENCES}

[1] Krahl, J.; Munack, A.; Schröder, O.; Stein, H.; Bünger, J.: Emissions- und Wirkungsvergleich verschiedener Dieselkraftstoffe mit Biodiesel. VDI Ber. Nr. 1808, 2003, VW Tagung Wolfsburg, Dez. 2003, S. 223.

[2] Hausberger, S.: Partikelemissionen eines GVBStadtbusses bei Betrieb mit Biodiesel und Potentiale von nachrüstbaren Abgasnachbehandlungssystemen. FVT Forschungsgesellschaft für Verbrennungskraftmaschinen und Thermodynamik mbH, TU Graz, Bericht-Nr. FVT03/6770-1, Mai 2003.

[3] EPA: A Comprehensive Analysis of Biodiesel Impacts on Exhaust Emissions. US Environmental Protection Agency, Report EPA 420-P-02-001, Oct. 2002.
[4] Mayer, A.; Czerwinski, J.; Wyser, M.; Mattrel, P.; Heitzer, A.: Impact of RME/Diesel Blends on Particle Formation, Particle Filtration and PAH Emissions. TTM, AFHB, BUWAL, EMPA, EV ; SAE Paper 2005-01-1728, Detroit Apr. 2005

[5] Trapel, E.; Roth, P.: Schadstoffreduzierung eines Dieselmotors mit Direkteinspritzung durch Einsatz von Fettsäure-Methylester, Universität Duisburg-Essen, MTZ $12 / 2004$, s. 1020

[6] $\mathrm{CO}_{2}$-neutrale Wege zukünftiger Mobilität durch Biokraftstoffe - eine Bestandsaufnahme, Literaturstudie des IFEU im Auftrag der Forschungsvereinigung Verbrennungskraftmaschinen FVV, Download möglich unter www.ufop.de, MTZ 12/2004, S. 954

[7] Mittelbach, M.; Remschmidt, C.: (2004) Biodiesel: The comprehensive handbook; Börsedruck GmbH, Wien, ISBN 3-200-00249-2

[8] www.biodiesel.ch, www.ecoenergie.ch

[9] Boehman, A.L.; Song, J.; Alam, M.: Impact of Biodiesel Blending on Diesel Soot and the Regeneration of Particulate Filters. Energy \& Fuels 2005, 19, 1857-1864.

[10] Song, J.; Alam, M.; Boehman, A.L.; Kim, U.: Examination of the oxidation behavior of biodiesel soot. Science Direct, Combustion and Flame 146 (2006) 589-604.

[11] Williams, A.; McCormick, R.L.; Hayes, R.R.; Ireland, J.; Fang, H.L.: Effect of Biodiesel Blends on Diesel Particulate Filter Performance. SAE Technical Paper 2006-01-3280. SAE International, Powertrain \& Fluid Systems Conference \& Exhibition, Toronto, Canada, October 16-19, 2006.

[12] Zabetta, E.C.; Hupa, M.; Niemi, S.: Bio-derived fuels may ease the regeneration of diesel particulate traps. Elsevier, Fuel 85 (2006) 2666-2670.

[13] Czerwinski, J.; Zimmerli, Y.; Mayer, A.; Heeb, N.; Lemaire, J.; D'Urbano, G.; Bunge, R.: Testing of Combined DPF+SCR Systems for HD-Retrofitting VERTdePN. SAE Technical Paper 2009-01-0284, Detroit, April 2009

[14] Czerwinski, J.; Zimmerli, Y.; Dimopoulus Eggenschwiler, P.; Heeb, N.; D’Urbano, G.; Mayer, A.: Influences of Biocomponents (RME) on Emissions of a Diesel Engine with SCR. TAE Technische Akademie Esslingen, $8^{\text {th }}$ International Colloquium "Fuels", January 2011, p. 493.

[15] Czerwinski, J.; Zimmerli, Y.; Mayer, A.; Heeb, N.; D'Urbano, G.: Diesel Emission with DPF+SCR in VERTdePN-Testing \& Potentials. SAE Paper 2011-01-1139, Detroit, April 2011.

[16] Mayer, A.; Czerwinski, J.: VERT Particulate Trap Verification. IX. International Conference " $R$ \& D of Internal Combustion Engines", Vladimir, Russia,

Page 15 of 16 
May 27-29,2003 (ISBN 5-86953-048-2) p. 92

(SAE 2002-01-0435).

[17] VERT Filter List, tested and approved particle trap systems for retrofitting Diesel engines, www.vert-certification.eu; www.vert-dpf.eu.

[18] Ullman, J.; Eppinger, D.; Stutzenberger, H.; Straub, G.: Factors Influencing Fuel Ageing - Conclusions from Laboratory Experiments and Investigations in Vehicle. $8^{\text {th }}$ International Colloquium "Fuels", TAE - Technische Akademie Esslingen, Jan. 11, ISBN 3-924813-86-8, p. 99

[19] Karavalakis, G.; Karonis, D.; Zannikos, F.; Stournas, S.: Evaluation of the Oxidation Stability of Diesel/Biodiesel Blends. $8^{\text {th }}$ International Colloquium "Fuels", TAE Technische Akademie Esslingen, Jan. 2011, ISBN 3-924813-86-8, p. 109

[20] Jansson, R.: Microorganisms Will Always be There, Waiting for the Next Opportunity to Proliferate. $8^{\text {th }}$ International Colloquium "Fuels", TAE - Technische Akademie Esslingen, Jan. 2011, ISBN 3-924813-86-8, p. 119

[21] Williams, A.; McCormick, R.; Luecke, J.; Brezny, R.; Geisselmann, A.; Voss, K.; Hallstrom, K.; Leustek, M.; Parsons, J.; Abi-Akar, H.: Impact of Biodiesel Impurities on the Performance and Durability of DOC, DPF and SCR Technologies. SAE Techn. Paper 2011-01-1136, SAE World Congress, Detroit April 12 $14^{\text {th }}-1011$.

\section{ABBREVIATIONS}

\begin{tabular}{|c|c|}
\hline AFHB & Abgasprüfstelle FH Biel, $\mathrm{CH}$ \\
\hline BAFU & $\begin{array}{l}\text { Bundesamt für Umwelt, } \mathrm{CH} \\
\text { (Swiss EPA, FOEN) }\end{array}$ \\
\hline $\mathrm{BfE}$ & Bundesamt für Energie \\
\hline BioExDi & $\underline{B i o f u e l s} \underline{\text { Exhaust Systems Diesel }}$ \\
\hline $\mathrm{Bxx}$ & 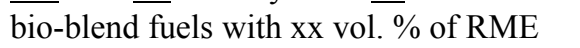 \\
\hline CFPP & cold filter plugging point \\
\hline CLD & chemoluminescence detector \\
\hline $\mathrm{CPC}$ & condensation particle counter \\
\hline $\mathrm{CR}$ & common rail \\
\hline $\mathrm{CSF}$ & Catalytic Soot Filter \\
\hline $\mathrm{DC}$ & Diffusion Charging Sensor \\
\hline dePN & de Particles + deNO $_{\mathrm{x}}$ \\
\hline DI & Direct Injection \\
\hline DiSC & Diffusion Charge Size Classifier \\
\hline DMA & differential mobility analyzer \\
\hline DOC & Diesel Oxidation Catalyst \\
\hline DPF & Diesel Particle Filter \\
\hline $\mathrm{EC}$ & $\begin{array}{l}\text { Elemental Carbon (VDI 2465) / European } \\
\text { Community }\end{array}$ \\
\hline ECU & electronic control unit \\
\hline EMPA & $\begin{array}{l}\text { Eidgenössische Material Prüf- und } \\
\text { Forschungsanstalt }\end{array}$ \\
\hline EPA & Environmental Protection Agency \\
\hline
\end{tabular}

Page 16 of 16

\begin{tabular}{|c|c|}
\hline ETC & European Transient Cycle \\
\hline $\mathrm{EV}$ & Erdöl Vereinigung \\
\hline FAME & Fatty Acid Methyl Ester \\
\hline $\mathrm{FE}$ & filtration efficiency \\
\hline FI & fuel injection (fuel aerosol generator) \\
\hline FID & flame ionization detector \\
\hline FL & full load \\
\hline FOEN & Federal Office of Environment \\
\hline FTIR & Fourrier Transform Infrared Spectrometer \\
\hline GFM & filter material $\mathrm{SiC}$ coated, $\mathrm{CSF}$ \\
\hline HD & heavy duty \\
\hline IARC & International Association of Research on Cancer \\
\hline ICE & internal combustion engines \\
\hline INSOF & insoluble fraction \\
\hline IR & increase rate, infrared \\
\hline $\mathrm{JRC}$ & EC Joint Research Center \\
\hline $\mathrm{K}_{\mathrm{x}}$ & conversion efficiency of the component " $\mathrm{x}$ " \\
\hline LD & low duty \\
\hline LDS & Laser Diode Spectrometer (for $\mathrm{NH}_{3}$ ) \\
\hline LEM & limited engine map \\
\hline MD19 & heated minidiluter \\
\hline & $\begin{array}{l}\text { NanoMetnanoparticle summary surface } \\
\text { analyser (PAS + DC + MD19) }\end{array}$ \\
\hline NP & nanoparticles < 999 nm (SMPS range) \\
\hline $\mathrm{OC}$ & Organic Carbon (VDI 2465) \\
\hline OEM & original equipment manufacturer \\
\hline OP & operating point \\
\hline PAH & Polycyclic Aromatic Hydrocarbons \\
\hline $\mathrm{PC}$ & particle counts \\
\hline $\mathrm{PCDD} / \mathrm{F}$ & Polychlorinnated Dibenzodioxins/Furans \\
\hline PCFE & particle counts filtration efficiency \\
\hline PM & particulate matter, particle mass \\
\hline PMFE & particle mass filtration efficiency \\
\hline $\mathrm{PN}$ & particle number \\
\hline PSD & particle size distribution \\
\hline $\mathrm{RE}$ & reduction efficiency \\
\hline RME & rapeseed methyl ester \\
\hline SCR & selective catalytic reduction \\
\hline SEM & scanning electron microscope \\
\hline SFM & filter material $\mathrm{SiC}$ uncoated \\
\hline $\mathrm{SiC}$ & silicium carbid \\
\hline SMPS & Scanning Mobility Particle Sizer \\
\hline SOF & soluble organic fraction \\
\hline SP & sampling position \\
\hline $\mathrm{TC}$ & thermoconditioner. Total Carbon \\
\hline TEF & toxicity equivalence factor \\
\hline TEM & transmission electron microscope \\
\hline TEQ & toxicity equivalence \\
\hline TTM & Technik Thermische Maschinen \\
\hline UDS & urea dosing system \\
\hline ULSD & ultra low sulfur Diesel \\
\hline \multirow[t]{4}{*}{ VERT } & Verminderung der Emissionen von \\
\hline & Realmaschinen in Tunelbau \\
\hline & 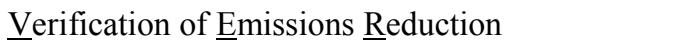 \\
\hline & Technologies \\
\hline VSCR & Vandium based SCR \\
\hline
\end{tabular}

